\title{
Impact of STAT3 phosphorylation in glioblastoma stem cells radiosensitization and patient outcome
}

\author{
Konstantin Masliantsevi,2,3, Baptiste Pinel ${ }^{4}$, Anaïs Balbous ${ }^{1,2,3}$, Pierre-Olivier \\ Guichet $^{1,2,3}$, Gaëlle Tachon ${ }^{1,2,3}$, Serge Milin ${ }^{5}$, Julie Godet ${ }^{5}$, Mathilde Duchesne ${ }^{5}$, \\ Antoine Berger ${ }^{4}$, Christos Petropoulos ${ }^{1,2,3}$, Michel Wager ${ }^{2,6}$ and Lucie Karayan- \\ Tapon $^{1,2,3}$ \\ ${ }^{1}$ Inserm U1084, Laboratoire de Neurosciences Expérimentales et Cliniques, Poitiers F-86073, France \\ ${ }^{2}$ Université de Poitiers, Poitiers F-86073, France \\ ${ }^{3} \mathrm{CHU}$ de Poitiers, Laboratoire de Cancérologie Biologique, Poitiers F-86022, France \\ ${ }^{4} \mathrm{CHU}$ de Poitiers, Service d'Oncologie Radiothérapique, Poitiers F-86021, France \\ ${ }^{5} \mathrm{CHU}$ de Poitiers, Service d'Anatomo-Cytopathologie, Poitiers F-86021, France \\ ${ }^{6} \mathrm{CHU}$ de Poitiers, Service de Neurochirurgie, Poitiers F-86021, France \\ Correspondence to: Lucie Karayan-Tapon, email: lucie.karayan-tapon@chu-poitiers.fr \\ Keywords: glioblastoma; Stat3; radioresistance; cancer stem cells; static \\ Received: October 26, $2017 \quad$ Accepted: November 29, $2017 \quad$ Published: December 16, 2017 \\ Copyright: Masliantsev et al. This is an open-access article distributed under the terms of the Creative Commons Attribution Li- \\ cense 3.0 (CC BY 3.0), which permits unrestricted use, distribution, and reproduction in any medium, provided the original author \\ and source are credited.
}

\section{ABSTRACT}

Glioblastoma (GBM) represents the most common and lethal primary malignant brain tumor. The standard treatment for glioblastoma patients involves surgical resection with concomitant radio and chemotherapy. Despite today's clinical protocol, the prognosis for patients remains very poor with a median survival of $\mathbf{1 5}$ months. Tumor resistance and recurrence is strongly correlated with a subpopulation of highly radioresistant and invasive cells termed Glioblastoma Stem Cells (GSCs). The transcription factor STAT3 has been found to be constitutively activated in different tumors including GBM and enhanced tumor radioresistance. In this study, we assessed radiosensitization of GSC lines isolated from patients by inhibition of STAT3 activation using Stattic or WP1066. We showed that inhibitor treatment before cell irradiation decreased the surviving fraction of GSCs suggesting that STAT3 inhibition could potentiate radiation effects. Finally, we investigated STAT3 activation status on 61 GBM clinical samples and found a preferential phosphorylation of STAT3 on Serine727 (pS727). Moreover, we found that pS727 was associated with a significant lower overall patient survival and progression-free survival but not pY705. Taken together, our results suggest that pS727-STAT3 could be a potential prognostic marker and could constitute a therapeutic target to sensitize highly radioresistant GSCs.

\section{INTRODUCTION}

Glioblastoma (GBM) is the most common and aggressive primary malignant brain tumor associated with a poor prognosis. Surgical resection followed by concomitant radiochemotherapy constitutes the gold standard treatment for glioblastoma patients [1]. Despite this intensive clinical protocol, the prognosis for patients remains very poor with a median survival of 15 months according to tumor radio- and chemo-resistance [2]. Treatment failure may be explained by the presence of highly radioresistant Glioblastoma Stem Cells (GSCs) [3-5]. This small tumor subpopulation shares properties with "normal" neural stem cells like selfrenewal activity and multilineage differentiation but shows strong tumorogenicity upon orthotopic transplantation in immunodeficient mice. GSCs represent a supplemental degree in resistance to treatment as they are less sensitive to radiotherapy and contribute to tumor radioresistance 
by preferential activation of DNA damage checkpoint responses and increased DNA repair capacity [6-9]. Several signaling pathways have been suggested as potential targets in cancer radioresistance including $\mathrm{PI} 3 \mathrm{~K} / \mathrm{Akt}, \mathrm{NF}-\kappa \mathrm{B}$, TGF- $\beta$, Notch, or STAT3 [10-14]. The transcription factor STAT3 has been shown to play a critical role in GSCs [15-18]. In 2009, Sherry et al. have shown for the first time that STAT3 was required for proliferation and maintenance of multipotency in GSCs [19]. This member of STAT (Signal Transducer and Activator of Transcription) family can be activated by various cytokines and growth factors like IL-6 and EGF as well as by oncogenic proteins such as Src and Ras [20-23]. STAT3 is canonically activated by phosphorylation of tyrosine 705 (pY705) by different tyrosine kinases including EGFR, Src, JAK or ERK [24-26]. STAT3 transcriptional activity can be modulated by phosphorylation of serine 727 (pS727) by various serine kinases like PKC, MAPKsor mTOR [27-30]. The activation of STAT3 in the cytoplasm leads to its dimerization by SH2 domains, translocation into the nucleus, DNA binding and transcriptional activation of genes involved in numerous biological processes. Indeed, STAT3 is implicated in inflammatory response, cell proliferation, angiogenesis and cell survival by regulation of anti-apoptotic gene expression such as Bcl-2 [31-34]. Constitutive activation of STAT3 is frequently found in cancers including GBM $[35,36]$. Furthermore, recombinant Erythropoietin Receptor, nonreceptor tyrosine kinase BMX, Enhancer of Zeste Homolog 2 or Toll-like receptor 9 were shown to promote GSC selfrenewal through activation of STAT3 [37-40]. STAT3 was also shown to be constitutively activated in GSCs and its inhibition impaired GSCs self-renewal and viability [18]. Finally, STAT3 was shown to be involved in radioresistance in breast cancer, colorectal cancer, and gliomas [41-43]. Recently, Ouedraogo et al. have shown that STAT3 inhibition by Gö6976 leads to radiosensitization of human conventional GBM cell lines [14]. In this present work, we assessed radiosensitization of patient-derived GSC lines by specific inhibition of STAT3 phosphorylation using Stattic, a small non-peptidic inhibitor of $\mathrm{SH} 2$ domain and using WP1066 preventing downstream activation of STAT3 [44, 45]. We also examined STAT3 phosphorylation status on 61 GBM clinical samples to evaluate the prognostic impact of pS727 and pY705.

\section{RESULTS}

\section{Inhibition of STAT3 phosphorylation affects GSC viability}

As STAT3 is strongly activated in several cancer cell types [46-48], we compared STAT3 activation in our GSCs with normal human Neural Stem Cells (H9-hNSC). We observed that STAT3 is constitutively phosphorylated on both Y705 and S727 in GSCs compared to H9-hNSC
(Supplementary Figure 1). As STAT3 is a key player in GSC proliferation and self-renewal, we examined the effect of its inhibition on GSC viability by MTS assay. We observed that Stattic inhibits cell proliferation of both GSC-2 and GSC-11 lines in a dose-dependent manner (Figure 1A). Half-maximal inhibitory concentration (IC50) was $2.2 \mu \mathrm{M}$ and $1.2 \mu \mathrm{M}$ whereas IC20 was 0.93 $\mu \mathrm{M}$ and $0.52 \mu \mathrm{M}$ for GSC-2 and GSC-11 respectively. WP1066 treatment was less toxic compared to Stattic as IC50 and IC20 were 3.6 $\mu \mathrm{M}$ and $2.6 \mu \mathrm{M}$ for GSC-11. As previous reports showed that Stattic can alter cell cycle distribution, we verified whether Stattic could affect GSC cell cycle $[49,50]$. As shown in Supplementary Figure 2, $5 \mu \mathrm{M}$ of Stattic does not significantly affect the percentage of cells in each phase of the cell cycle. Finally, we examined the effect of Stattic and WP1066 on pY705 and pS727 by western blotting and showed a strong decrease of both phosphorylations (Figure 1B).

\section{Radiations increase S727 but not Y705 phosphorylation of STAT3}

Several studies have shown that radiations increase STAT3 phosphorylation in tumoral cells [51, 52]. To address the effects of radiations on STAT3 phosphorylation, we irradiated GSC- 2 and GSC- 11 cell lines at different doses. Lysates of the above cell lines were extracted and the phosphorylation levels of STAT3 on S727 and Y705 were analyzed by Western Blotting (Figure 2A). Twenty-four hours after irradiation, we observed a significant increase of pS727 in both cell lines compared to pY705 (Figure 2B). These results support the idea that irradiation leads to STAT3 activation which may enhance GSC radioresistance.

\section{Stattic pretreatment radiosensitizes GSCs}

Since irradiation induced STAT3 activation, we examined whether STAT3 inhibition by Stattic may have a radiosensitizing effect on GSCs. For that purpose, GSC2 and GSC-11 cell lines were pretreated or not (control) with infra-cytotoxic concentration of Stattic or WP1066 $(<\mathrm{IC} 20)$. Pretreatment with STAT3 inhibitors at low doses has no effect on cells' ability to form colonies as evaluated by a clonogenic assay 21 days after plating (Figure $3 \mathrm{~A}$ ). As shown in Figure 3B, radiations combined with Stattic pretreatment drastically decreased the surviving fraction of both GSC lines compared to radiation alone, thereby indicating a radiosensitization effect of STAT3 inhibition $(\mathrm{ER}>1)$. More interestingly, when radiations were associated with Stattic, the effect was found to be statistically significant $(p<0.05)$ at low radiation doses of 2 and 4 Gy for GSC-11 and 4 Gy for GSC-2 (Figure 3C). Additionally, radiosensitization effect of STAT3 inhibition was confirmed on GSC-11 using WP1066 treatment. Thus, we concluded that infra-cytotoxic doses of Stattic 
or WP1066 potentiate radiation-induced self-renewal inhibition of GSC lines.

\section{STAT3 preferential activation by $\mathrm{pS727}$ is related to GBM patient outcome}

To investigate the activation pattern of STAT3 in clinical samples, we assessed pY705, pS727 and total STAT3 by immunohistochemistry (IHC) on Tissue Microarray comprising samples of 61 patients with
GBM (Figure 4A). First, we found that all samples were positive for $\mathrm{pS} 727$ whereas $74 \%$ of these samples showed pY705 staining thereby suggesting an important role of pS727 activation in GBM (Figure 4B). Moreover, 77\% of samples presented a low or negative staining for $\mathrm{pY} 705$ and only $8 \%$ were associated with a high level staining. On the contrary, concerning pS727 immunolabeling, $33 \%$ of the above cases exhibited low staining levels whereasile $33 \%$ were highly stained. Finally, we evaluated the prognostic role of pS727 and pY705 on our patient's

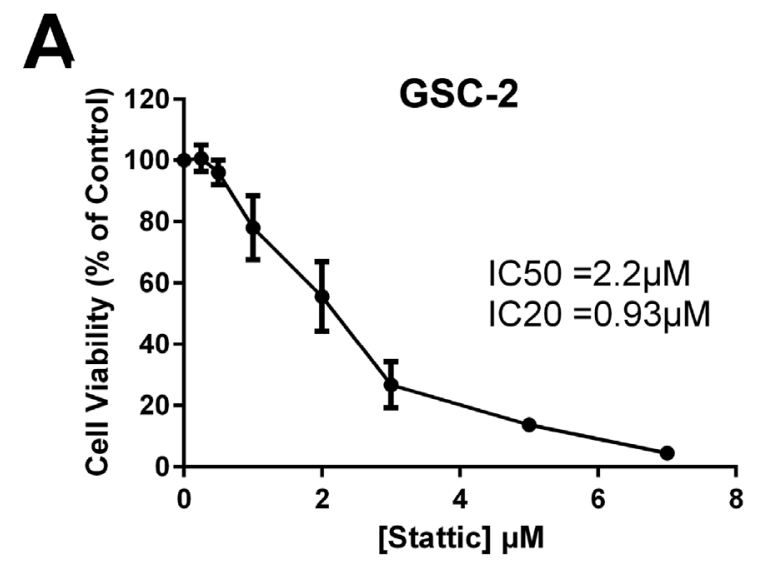

B

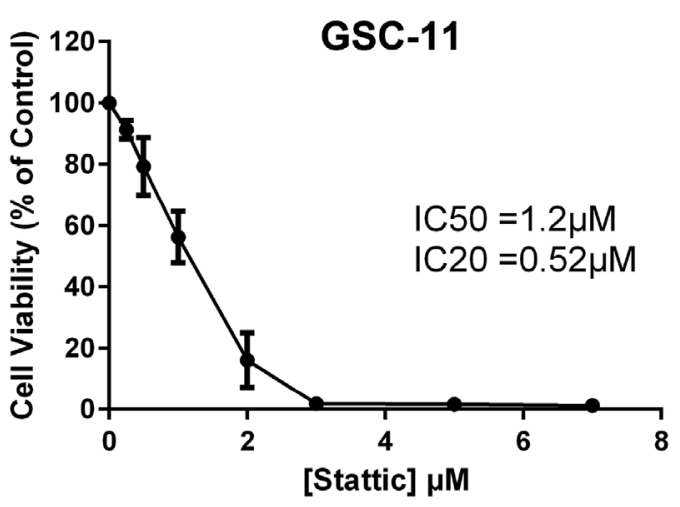

GSC-11

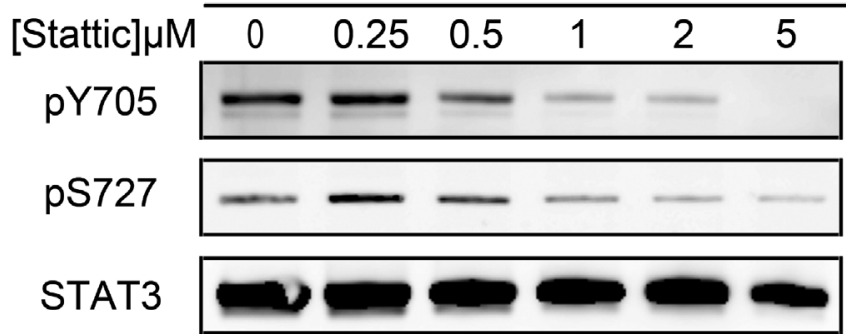

ACTIN

GSC-2
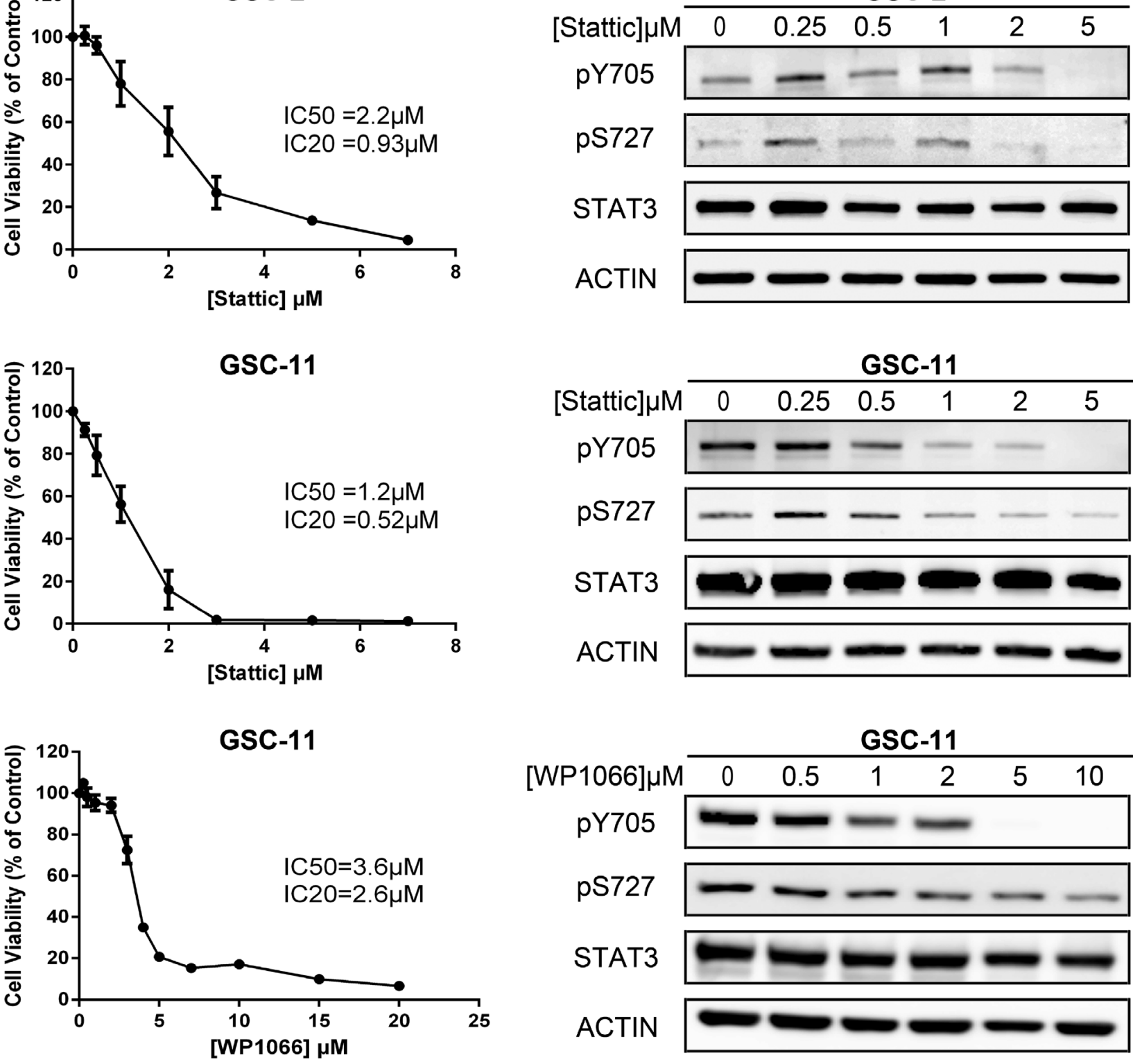

GSC-11

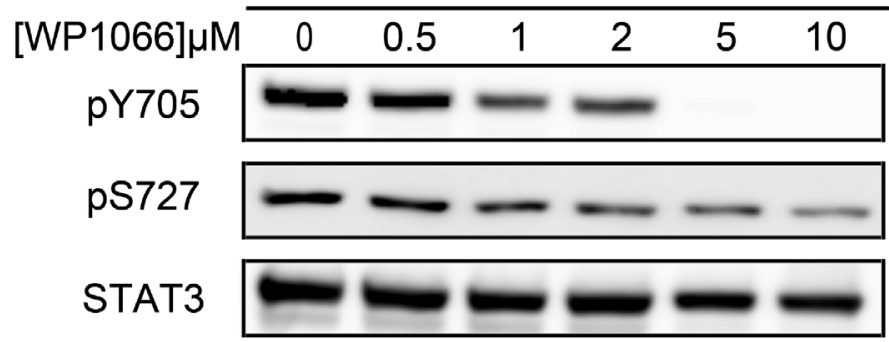

ACTIN

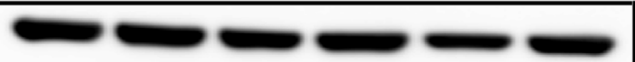

Figure 1: Effect of STAT3 inhibition in GSC lines. (A) GSC viability was assessed by MTS assay after 5 days of Stattic or WP1066 treatment. The half maximal inhibitory concentrations IC50 and IC20 are indicated in the panel. Each point represents the mean of at least 3 independent experiments. Error bars show \pm the standard error of the mean. (B) Western Blot analysis of STAT3 phosphorylation status after treatment with indicated doses of each inhibitor. No major modification of total STAT3 expression was observed. Actin was used as internal control. This experiment was repeated 3 times. 
cohort. The analysis of Kaplan-Meier survival curves showed that a high level of pS727 was associated with a lower overall survival $(p=0.0044)$ and progressionfree survival $(p=0.0452)$ whereas no correlations were found for $\mathrm{pY} 705$ ( $p=0.4344$ and $p=0.5039$ respectively) (Figure 5A and 5B). Taken together, these data suggest that pS727-STAT3 has a prognostic value and could be involved in GBM aggressiveness and resistance.

\section{DISCUSSION}

Concomitant chemo and radiotherapy after surgery represent the "gold standard" for initial treatment of GBM. Despite this aggressive therapy, relapse ineluctably occurs, principally due to tumor resistance. This therapeutic failure may be explained by the presence of highly radioresistant GSCs which constitute an additional degree of resistance and could be one of the main causes of tumor relapse. Many avenues have been suggested to target pathways involved in gliomagenesis and therapeutic resistance in order to increase treatment efficiency and patient survival. Transcriptional factor STAT3 was proposed as a potential
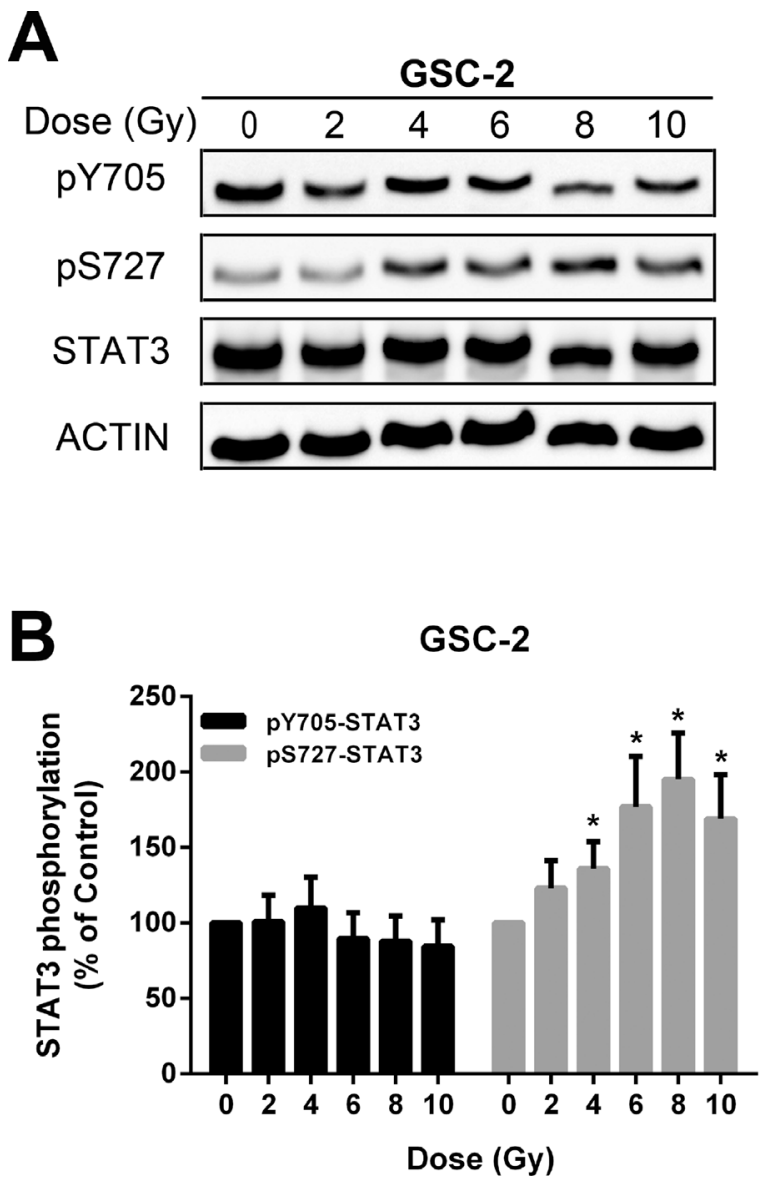

target for tumor radiosensitization. Indeed, STAT3 is a major actor of cell survival after therapy by regulating the expression of anti-apoptotic genes such as $B c l-x L$ or $M c l$ 1 in glioblastoma [53]. Moreover, STAT3 was shown to be necessary for efficient repair of damaged DNA, partly by modulating the ATM-Chk2 and ATR-Chk1 pathways [54]. Recently, $\mathrm{Xu}$ et al. have shown that autophagy promotes the repair of radiation-induced DNA damage in bone marrow hematopoietic cells through the activation of STAT3, leading to upregulation of expression of BRCA1 [55]. Furthermore, several studies have demonstrated that the inhibition of STAT3 led to radiosensitization of different cancer cell lines including breast, colorectal, uterine, head and neck and brain cancers [14, 41, 42, $56,57]$. In 2016, Ouédraogo et al. proposed that pS727STAT3 constitute a relevant target for radiosensitization in human GBM cell lines. However, radiosensibility after STAT3 inhibition was only observed for conventional cell lines which present pS727 without pY705 [14].

In this work, we investigated the radiosensitizing effect of STAT3 inhibition by Stattic in two patient derived GSC lines and assessed the prognostic impact
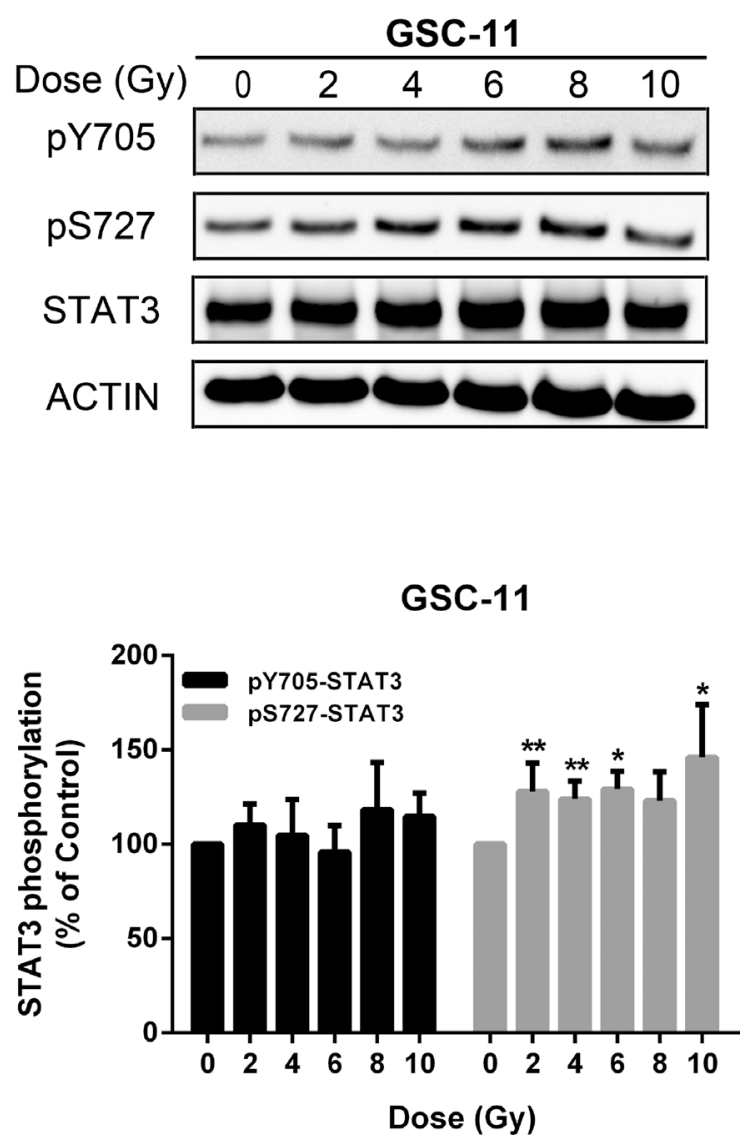

Figure 2: Radiations enhance STAT3 activation mainly by S727 phosphorylation. (A) Western blot analysis of STAT3 phosphorylation status $24 \mathrm{~h}$ after treatment at increasing doses of radiations in GSC-2 and GSC-11. (B) Quantification of experiment presented in (A). Histogram represents the mean \pm standard error of the mean of 6 independent experiments $\left({ }^{*} p<0.05 ;{ }^{* *} p<0.01 ;\right.$ MannWhitney test). 
A
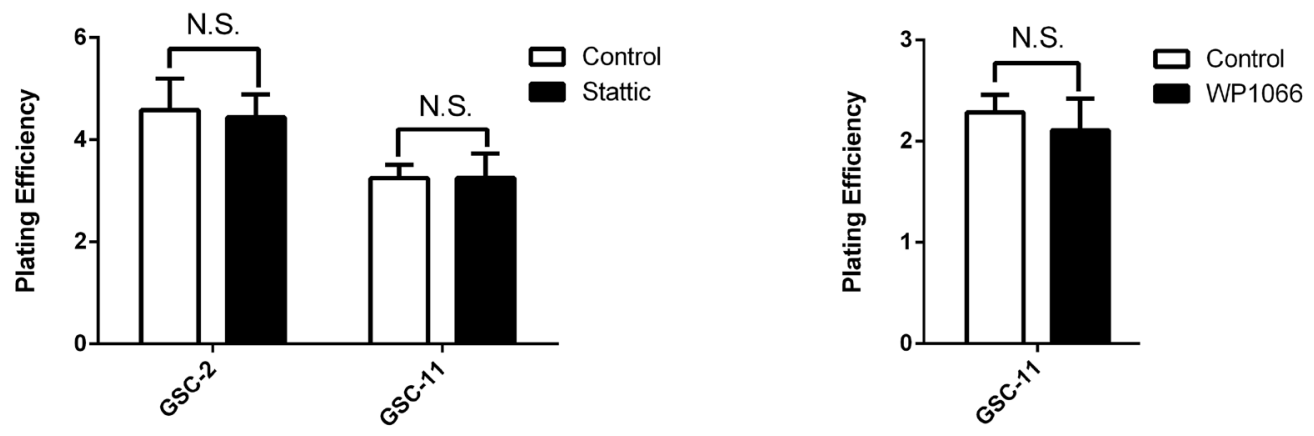

B
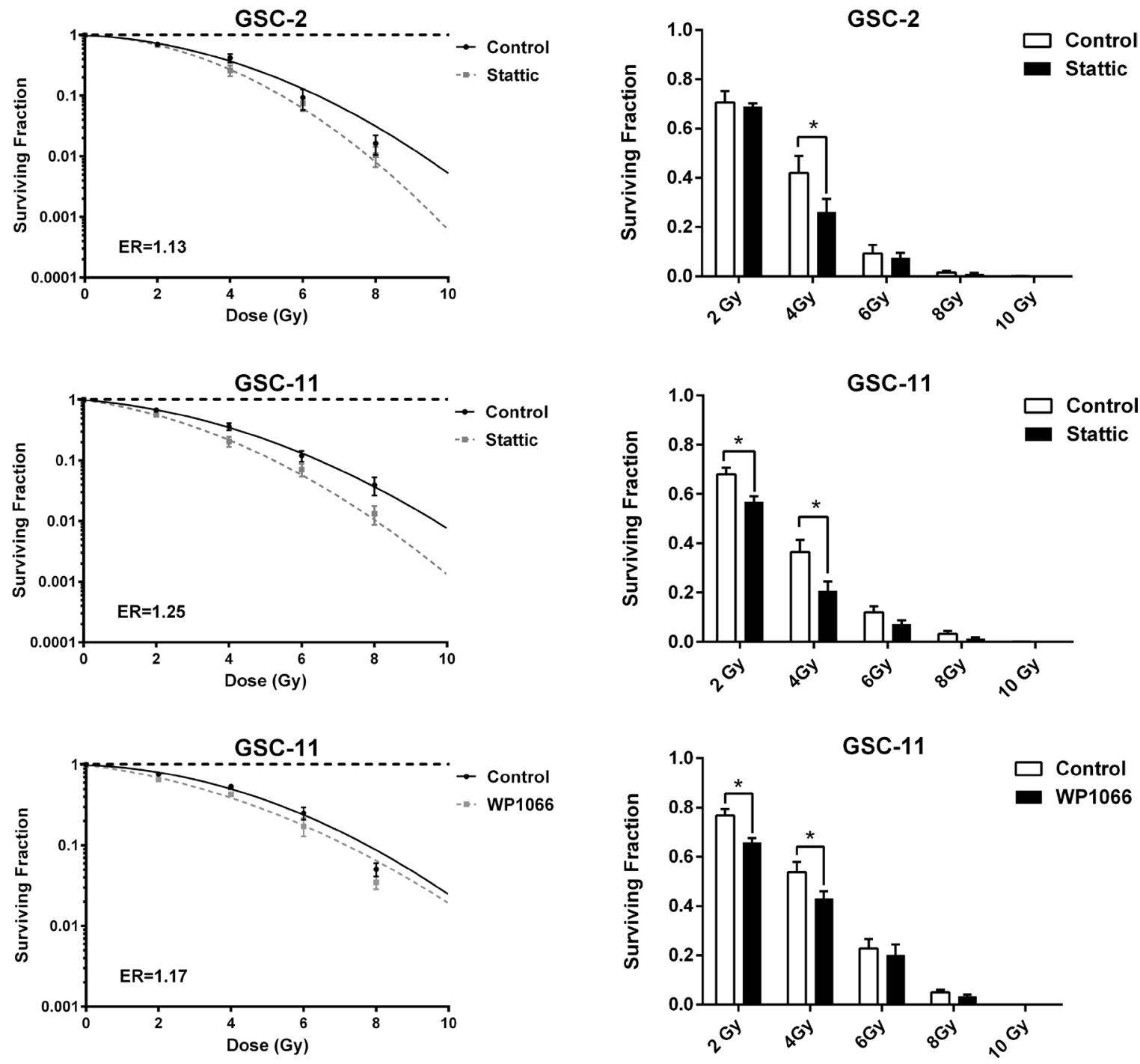

Figure 3: STAT3 inhibition radiosensitizes GSCs. (A) Plating efficiency of GSC lines in control conditions compared with Stattic or WP1066 pretreatment in the absence of irradiation (N.S. not significant, Mann-Whitney test). (B) Clonogenic survival curves of GSCs treated with irradiation alone or in combination with STAT3 inhibitors were assessed using the linear quadratic model. The mean inactivation dose equal to the area under the survival curves was calculated and the cell survival enhancement ratio (ER) was determined as the ratio of the mean inactivation dose under control conditions divided by the mean inactivation dose after inhibitor treatment.A ratio superior to 1 indicates radiosensitization of GSCs. (C) Comparison of cell surviving fractions after inhibitor treatment for each dose of radiation. Histograms represent the mean \pm standard error of the mean of 4 independent experiments $\left({ }^{*} p<0.05\right.$, Multiple comparison $t$-test $)$. 

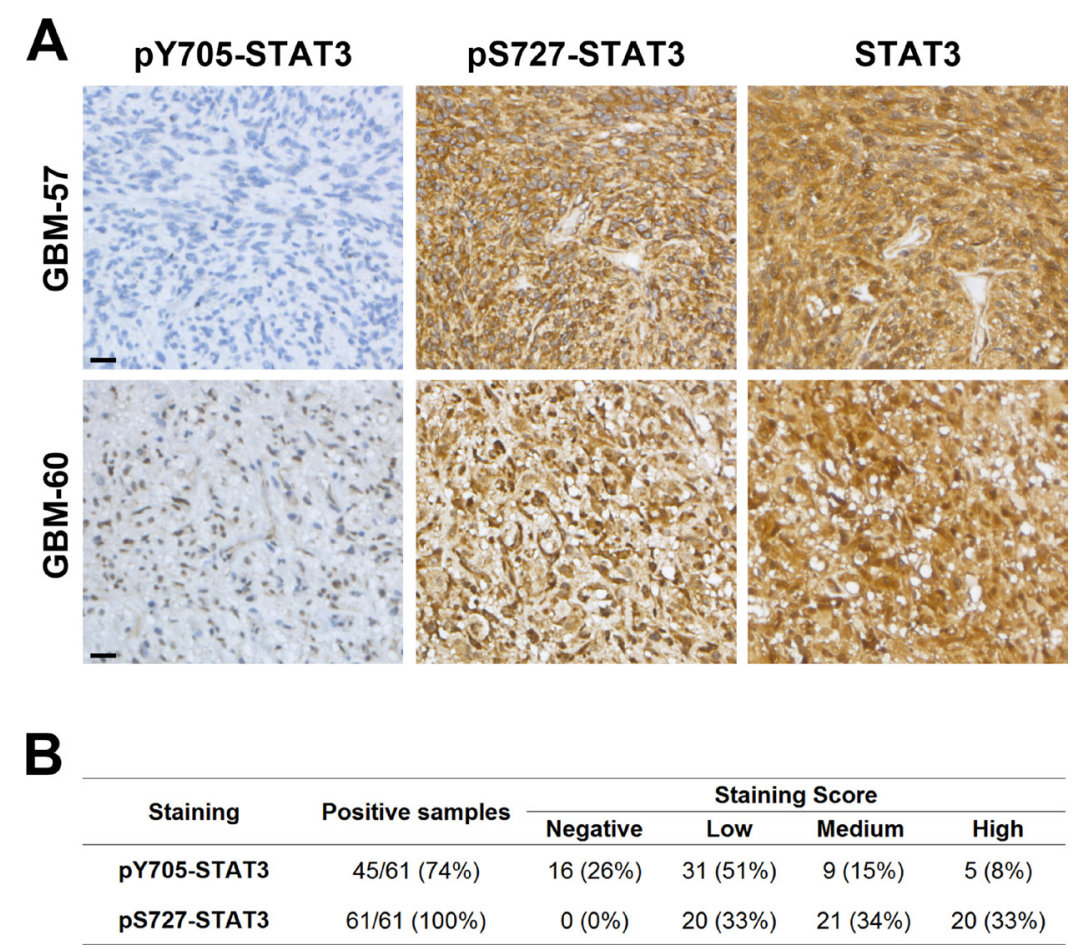

Figure 4: STAT3 is preferentially activated by pS727 in GBM clinical samples. (A) Examples of immunohistochemical staining to detect the phosphorylation of Y705 and S727 or the expression of total STAT3 in 2 GBM samples. Scale bar $=20 \mu \mathrm{m}$. (B) Number and percentage of positive samples and staining score for pY705 and pS727 ( $n=61$ patients).
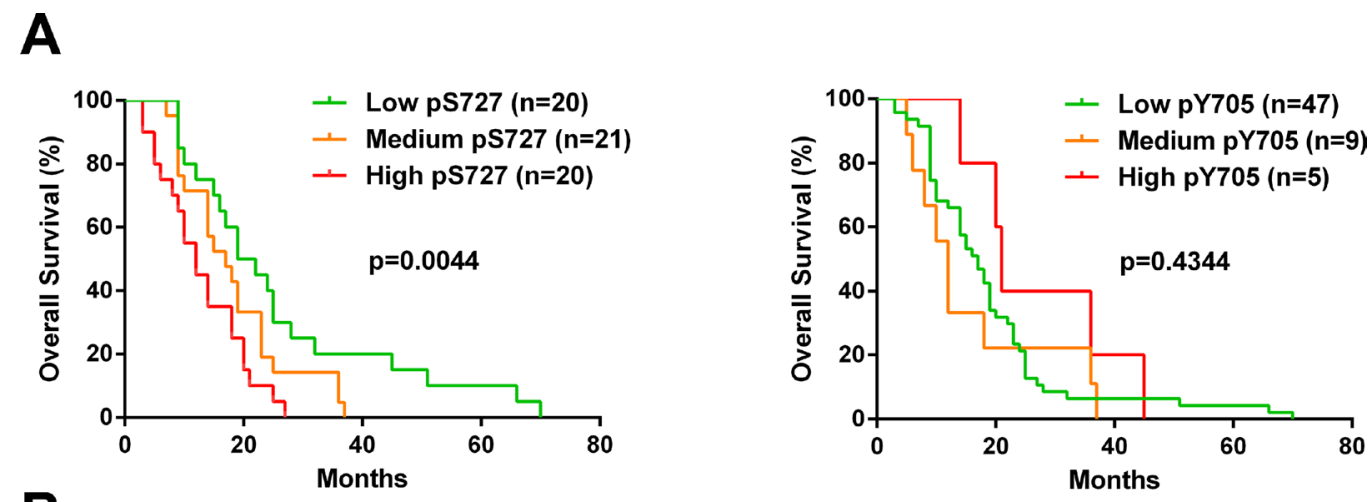

B
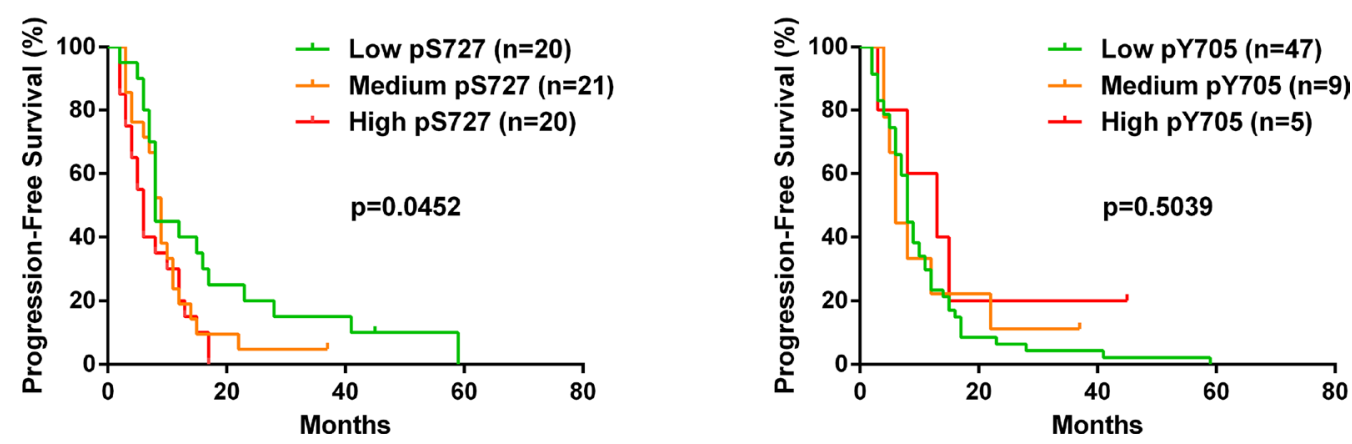

Figure 5: S727 phosphorylation but not Y705 affects the outcome of GBM patients. Kaplan-Meier curves of all glioblastoma patients plotting overall survival (A) or progression-free survival (B) of patients with low, medium or high score for pY705 and pS727 staining. For this analysis, patients presenting negative or low staining score were pooled. Mantel-Cox log rank test was performed to determine the $p$-value indicated on the graphs. 
of STAT3 activation in 61 GBM clinical samples. First, we showed that STAT3 is constitutively activated in our GSC lines confirming our previous report [18]. Moreover, this activation is increased by radiation treatment mainly on pS727. Stattic inhibitor induces a strong decrease of both pY705 and pS727 phosphorylations in GSCs. For determination of conjugated effect of STAT3 inhibition with radiations, we used infra-cytotoxic dose $(<\mathrm{IC} 20)$ of Stattic to exclude inhibitory effect alone. For both GSCs, Stattic potentiated radiation effect by decreasing GSC self-renewal. This effect was more important for low radiation doses at 2 and 4 Gy corresponding to daily fractions of radiotherapy received by GBM patients. We also confirmed the strategy of STAT3 inhibition for GSC radiosensitization using a second inhibitor, WP1066. Our results showed that STAT3 inhibition led to radiosensitization even in the presence of both STAT3 phosphorylated forms in opposition to previous results reported by Ouédraogo et al. However, these results corroborate the fact that $\mathrm{S} 727$ phosphorylation constitutes an interesting target to sensitize GSCs to irradiation.

Over the last decade several STAT3 inhibitors have been studied but Stattic has been the first nonpeptidic small molecule to demonstrate selective inhibition function over the STAT3 SH2 domain regardless of the STAT3 activation state in vitro [44]. Other STAT3 inhibitors are currently used for targeting the STAT3 pathway in cancer, including GBM. Cucurbitacin-I and WP1066 administration or shRNA knockdown resulted in on-target JAK2/STAT3 inhibition and dramatically reduced GBM-derived Brain tumor stem cells [17]. Moreover, STX-0119 inhibitor of STAT3 dimerization has shown antitumor effects on GSC lines without significant decrease of pY705 [58]. WP1066, one of the most promising STAT3 inhibitor, will be investigated in phase I clinical trial for patients with recurrent malignant glioma and brain metastasis from melanoma (scheduled for 2017, ClinicalTrials.gov). As WP1066 is orally bioavailable and crosses the bloodbrain barrier, it could be a promising inhibitor of STAT3 in clinical treatment of GBM [59]. OPB-31121 is another promising STAT3 inhibitor which presents notably higher affinity for STAT3, stronger efficacy for pY705 and pS727 inhibition and is associated with a lower toxicity than other STAT3 inhibitors. This inhibitor induces a strong decrease of cell proliferation and clonogenicity in prostate cancer cell lines [60]. In addition, OPB-31121 has been tested in a phase I clinical trial, showing antitumoral activity with relatively good tolerance and demonstrating feasibility of STAT3 inhibition in patients with solid tumors [61]. Altogether, these data demonstrated the potential role of STAT3 inhibitors in cancer treatment, however these molecules cannot distinguish which activation of STAT3 could be at the origin of tumor resistance as there are no pS727 specific inhibitors.

In our study, we observed that GSC lines showed different sensibility in term of response to Stattic treatment with almost a 2 fold change in IC50 and IC20 values. This could be explained by tumor heterogeneity with distinct genetic profiles. Indeed, GBMs were classified into four different groups (classical, mesenchymal, neural and proneural) according to their molecular and transcriptome profiles referred to as Verhaak's classification [62]. These subtypes present different microenvironments and are regulated by different signaling pathways. The mesenchymal subtype was shown to be particularly malignant and associated with a poor prognosis [63]. In brain tumors, STAT3 was shown to play a critical role in mesenchymal transition associated with angiogenesis, extensive necrosis and enhanced inflammatory response $[15,64-66]$. The experimental differences between our GSC lines could be explained by inter and intra-tumor heterogeneity.

Immunohistochemical analysis of pS727 and pY705 in our 61 GBM samples showed that pS727 was present in all patients with higher staining scores than pY705. Moreover, we found that pS727 negatively impacts patient outcome in a way that is concordant with previous reports showing the association of pS727 with lower patient survival and faster relapse [14, 67]. However, we did not find any association for pY705 in contrast to previous studies which have also shown a prognostic role for $\mathrm{pY} 705$ [68]. This could be explained by the limits of sensitivity and specificity of the diagnosis and of the detection methods as well as by the sampling and monitoring of patients. In our cohort, all patients were deceased at the time of the study removing bias due to censored subjects in Kaplan-Meier survival curve analysis.

In conclusion, our results show pS727 as prognostic factor for patient survival and confirm the strategy of GSC radiosensitization by STAT3 inhibition. The high level of pS727 could confer a radioresistance of GBM tumor and explain faster relapse after current radio-chemotherapy treatment, supporting the idea of pS727-STAT3 inhibition as innovative targeted therapy. However, genetic background of tumor could modulate the therapeutic response, suggesting that the strategy to enhance tumor radiosensitivity by STAT3 inhibition could be applied to STAT3-dependant GBMs, especially these of the mesenchymal subtype.

\section{MATERIALS AND METHODS}

\section{Cell culture}

Glioblastoma stem cell cultures were derived from adult patients with high-grade gliomas operated in the University Hospital of Poitiers after informed consent of all patients as previously described $[9,18,69,70]$. Briefly, both GSC lines were assessed for stemness, self-renewal and differentiation in vitro, then tumorigenicity was evaluated by xenografts in immunodeficient mice. Cells were cultured in Neurobasal ${ }^{\circledR}$ Medium (NBE) $\left(\right.$ Gibco $\left.^{\circledR}\right)$ 
supplemented with B27 1\%; N2 0.5\%; bFGF 0.05\% and EGF $0.005 \%\left(\right.$ Gibco $\left.^{\circledR}\right)$ at $37^{\circ} \mathrm{C}$ in $5 \% \mathrm{CO}_{2}$ humidified incubator. Culture medium was replaced twice a week and when spheres became large and numerous, they were enzymatically dissociated with accutase (Merck Millipore).The molecular characteristics of the GSC-2 and GSC-11 including MGMT promoter methylation, EGFR copy number, IDH1, IDH2, EGFR-variant III, p53, PTEN status as well as LOH at loci 1p36, 19q13, 9p21 and 10q23 are provided in supplemental table S1. Human Neural Stem Cells (H9-NSCs) (Gibco ${ }^{\circledR}$ ) were cultured following the manufacturer's instructions.

\section{Cell viability assay}

The MTS cell test (CellTiter $96^{\circledR}$ Aqueous NonRadioactive Cell Proliferation Assay (Promega)) was used to determine cell viability. Cells were seeded in a 96-well plates at 50000 cells per plate and treated one day after with appropriate dose of Stattic (Merck Millipore) or WP1066 (Santa Cruz Biotechnology). Five days later, quantification of viable cells was performed at $492 \mathrm{~nm}$ with a micro plate reader (Dynex Technologies, Chantilly, France).

\section{Cell irradiation}

Cell irradiation was performed at the Department of Radiotherapy of the University Hospital of Poitiers. Cells were submitted to gamma irradiation with a linear accelerator Elekta Synergy Beam Modulator (4.56 Gy/min).

\section{Western blot}

Cells were lysed $7 \mathrm{~h}$ after Stattic treatment, $6 \mathrm{~h}$ after WP1066 treatment or $24 \mathrm{~h}$ after irradiation with a cold RIPA buffer and protein concentration was determined using a Bradford assay (Bio-rad). An equal quantity of protein samples was separated by SDS-PAGE and transferred onto a nitrocellulose membrane (Bio-rad). Membrane was blocked with Phosphate-buffered saline (PBS 1X) containing 0.1\% Tween 20 (Sigma) and 5\% nonfat dry milk. Primary antibodies were incubated overnight at $4^{\circ} \mathrm{C}$ (Stat3 1:1250 (\#9136); phosphor-Stat3 Tyr705 1:500 (\#9131); phosphor-Stat3 Ser727 1:500 (\#9136) Cell Signaling Technology; Actin 1:5000 (\#ab3280) Abcam). Secondary antibodies were incubated for $1 \mathrm{~h} 30$ at room temperature (Anti-mouse HRP-linked 1:2000 (\#7076); Anti-rabbit HRP-linked 1:2000 (\#7074) Cell Signaling Technology). Immunoblotting signals were detected using an enhanced chemiluminescence method (Clarity ${ }^{\mathrm{TM}}$ Western ECL Substrate, Bio-rad) with Luminescent Image Analyzer LAS-3000 (FUJIFILM). Densitometry analyses were performed using ImageJ software (imagej. nih.gov/ij/). Relative amounts of pY705 and pS727 were normalized to total STAT3 and Actin.

\section{Clonogenic assay}

Neurospheres were dissociated and treated with appropriate doses of Stattic $(<\mathrm{IC} 20 ; 0.5 \mu \mathrm{M}$ for GSC-11 and $0.25 \mu \mathrm{M}$ for GSC-2) or WP1066 $(<\mathrm{IC} 20 ; 1.5 \mu \mathrm{M})$ for $7 \mathrm{~h}$ and $6 \mathrm{~h}$ respectively prior to irradiation. Cells were plated in triplicate at a density of $4 \times 10^{4}$ cells per $35 \mathrm{~mm}$ dish in methylcellulose medium (Neural Cell Cloning Medium-S1, Stem Cells Technology) supplemented with B27 1\%; N2 0.5\%; bFGF 0.05\%; EGF 0.005\% and subjected to various doses of irradiation $(2,4,6,8$ and $10 \mathrm{~Gy})$. After 21 days of incubation, formed colonies were counted under inverted microscope (Nikon). Survival curves were obtained using linear-quadratic model: Surviving Fraction $=e^{-\alpha(D+\beta D 2)}$. The mean inactivation dose equal to the area under the survival curves was calculated and the cell survival enhancement ratio (ER) was determined as the ratio of the mean inactivation dose under control conditions divided by the mean inactivation dose after inhibitor treatment. A ratio superior to 1 indicates radiosensitization of GSCs.

\section{Tissue Microarray (TMA) construction, immunohistochemistry and scoring}

TMAs were constructed using formalin-fixed paraffin embedded tissue samples that represent a total of 61 GBM from surgical resection or biopsy patients operated at the University Hospital of Poitiers. Patient characteristics are summarized in supplemental table $\mathrm{S} 2$. All of these patients were treated with radiotherapy and temozolomide. Original slides were reviewed to confirm GBM histology according to the 2007 World Health Organization classification system. For each case, a minimum of 3 cores were transferred from the selected areas to the recipient block, using a TMA workstation (Alphelys, Plaisir, France). The recipient block was cut into $3 \mu \mathrm{m}$ thick section, and immunochemistry was performed with an automated system (BenchMark XT, Ventana, Roche). Briefly, slides were deparaffinized and heated in sodium citrate $\mathrm{pH} 6$ solution for antigenic retrieval. Primary antibodies were incubated overnight at $4{ }^{\circ} \mathrm{C}$ (phospho-Stat3 Tyr705 1:100 (\#9131); phosphoStat3 Ser727 1:200 (\#9136); Stat3 1:1250 (\#9136) Cell Signaling Technology) and revealed using the streptavidinbiotin-peroxidase method with diaminobenzidine as chromogen (UltraView universal DAB detection kit, Roche). Scoring of antibody staining was evaluated independently by two pathologists in a blind manner. For both pY705 and pS727 staining, the percentage of stained tumor cells was multiplied by staining intensity (weak $=1$, moderate $=2$ or strong $=3$ ) to get a score between 0 and 300. Patient samples were categorized according to the statistical distribution of staining scores into 3 groups: Low, Medium or High. Survival rates were estimated by the Kaplan-Meier method. 


\section{Cell cycle analysis}

GSCs were treated with $5 \mu \mathrm{M}$ of Stattic during 7 hours. Then, cells were fixed with $70 \%$ ethanol at $-20^{\circ} \mathrm{C}$, washed once with cold PBS $1 \mathrm{X}$ and resuspended in DNA staining solution $(2.5 \mu \mathrm{g} / \mathrm{ml}$ Propidium Iodide, $0.5 \mathrm{mg} /$ $\mathrm{ml}$ RNase A) (MerckMillipore). Cell cycle redistribution was measured by flow cytometry on a FACS Canto II (BD Biosciences). Data analysis was performed using FlowJo ${ }^{\circledR}$ software (LLC). A total of 10000 events were analyzed in 4 independent experiments.

\section{Statistical analysis}

Descriptive statistics of the results were calculated with GraphPad Prism 6 (La Jolla, CA, USA). All experiments were performed at least three times. The results are presented as mean \pm standard error of the mean (SEM) and statistical significance was evaluated by Mann-Whitney test or multiple comparison $t$-test $\left({ }^{*} p<0.05\right)$. Log-rank (Mantel-Cox) test was applied to Kaplan-Meier survival curves and exact p-values were indicated.

\section{Abbreviations}

Bcl-2: B-cell lymphoma 2; EGFR: Epidermal Growth Factor Receptor; ER: enhancement ratio; ERK: extracellular signal-regulated kinase; GBM: Glioblastoma; GSCs: Glioblastoma Stem Cells; IHC: immunohistochemistry; JAK: Janus kinase; PI3K: MAPKs: Mitogen-activated protein kinases; mTOR: mechanistic target of rapamycin; Phosphoinositide 3-kinase; PKC: Protein kinase C; STAT3: Signal Transducer and Activator of Transcription 3; TGF- $\beta$ : Transforming growth factor beta; TMA: Tissue Microarray.

\section{Author contributions}

Conception and design: KM, BP, ABs, LKT; Collection and/or assembly of data: KM, BP, ABs, POG, JG, MD; Data analysis and interpretation: $\mathrm{KM}, \mathrm{BP}, \mathrm{ABs}, \mathrm{POG}, \mathrm{MD}$, LKT; Manuscript writing: KM, POG, GT, CP, LKT; Final approval of manuscript: KM, POG, GT, CP, MW, LKT; Provision of study material or patients: $\mathrm{MW}, \mathrm{SM}, \mathrm{ABr}$

\section{ACKNOWLEDGMENTS}

The authors would like to thank "En avant la vie" for their support and Jeffrey Arsham, an American medical translator, for having reread and reviewed the original English-language text.

\section{CONFLICTS OF INTEREST}

The authors have no conflicts to disclose.

\section{GRANT SUPPORT}

This work was supported by Ligue contre le Cancer de la Vienne et des Deux-Sèvres and the association "Sport et Collection". Konstantin Masliantsev PhD thesis is supported by the association "En avant la vie".

\section{REFERENCES}

1. Stupp R, Mason WP, van den Bent MJ, Weller M, Fisher B, Taphoorn MJ, Belanger K, Brandes AA, Marosi C, Bogdahn U, Curschmann J, Janzer RC, Ludwin SK, et al. Radiotherapy plus concomitant and adjuvant temozolomide for glioblastoma. N Engl J Med. 2005; 352:987-96. https:// doi.org/10.1056/NEJMoa043330.

2. Ostrom QT, Bauchet L, Davis FG, Deltour I, Fisher JL, Langer CE, Pekmezci M, Schwartzbaum JA, Turner MC, Walsh KM, Wrensch MR, Barnholtz-Sloan JS. The epidemiology of glioma in adults: a "state of the science" review. Neuro Oncol. 2014; 16:896-913. https://doi. org/10.1093/neuonc/nou087.

3. Galli R, Binda E, Orfanelli U, Cipelletti B, Gritti A, De Vitis S, Fiocco R, Foroni C, Dimeco F, Vescovi A. Isolation and characterization of tumorigenic, stem-like neural precursors from human glioblastoma. Cancer Res. 2004; 64:7011-21. https://doi.org/10.1158/0008-5472.CAN-04-1364.

4. Singh SK, Clarke ID, Terasaki M, Bonn VE, Hawkins C, Squire J, Dirks PB. Identification of a cancer stem cell in human brain tumors. Cancer Res. 2003; 63:5821-8.

5. Yuan X, Curtin J, Xiong Y, Liu G, Waschsmann-Hogiu S, Farkas DL, Black KL, Yu JS. Isolation of cancer stem cells from adult glioblastoma multiforme. Oncogene. 2004; 23:9392-400. https://doi.org/10.1038/sj.onc.1208311.

6. Bao S, Wu Q, McLendon RE, Hao Y, Shi Q, Hjelmeland AB, Dewhirst MW, Bigner DD, Rich JN. Glioma stem cells promote radioresistance by preferential activation of the DNA damage response. Nature. 2006; 444:756-60. https:// doi.org/10.1038/nature05236.

7. Kang MK, Hur BI, Ko MH, Kim CH, Cha SH, Kang SK. Potential identity of multi-potential cancer stemlike subpopulation after radiation of cultured brain glioma. BMC Neurosci. 2008; 9:15. https://doi. org/10.1186/1471-2202-9-15.

8. Lim YC, Roberts TL, Day BW, Harding A, Kozlov S, Kijas AW, Ensbey KS, Walker DG, Lavin MF. A role for homologous recombination and abnormal cellcycle progression in radioresistance of glioma-initiating cells. Mol Cancer Ther. 2012; 11:1863-72. https://doi. org/10.1158/1535-7163.MCT-11-1044.

9. Balbous A, Cortes U, Guilloteau K, Rivet P, Pinel B, Duchesne M, Godet J, Boissonnade O, Wager M, Bensadoun RJ, Chomel JC, Karayan-Tapon L. A radiosensitizing effect of RAD51 inhibition in glioblastoma stem-like cells. BMC Cancer. 2016; 16:604. https://doi. org/10.1186/s12885-016-2647-9. 
10. Hambardzumyan D, Becher OJ, Rosenblum MK, Pandolfi PP, Manova-Todorova K, Holland EC. PI3K pathway regulates survival of cancer stem cells residing in the perivascular niche following radiation in medulloblastoma in vivo. Genes Dev. 2008; 22:436-48. https://doi. org/10.1101/gad.1627008.

11. Ahmed KM, Li JJ. ATM-NF-kappaB connection as a target for tumor radiosensitization. Curr Cancer Drug Targets. 2007; 7:335-42.

12. Wiegman EM, Blaese MA, Loeffler H, Coppes RP, Rodemann HP. TGFbeta-1 dependent fast stimulation of ATM and p53 phosphorylation following exposure to ionizing radiation does not involve TGFbeta-receptor I signalling. Radiother Oncol. 2007; 83:289-95. https://doi. org/10.1016/j.radonc.2007.05.013.

13. Wang J, Wakeman TP, Lathia JD, Hjelmeland AB, Wang XF, White RR, Rich JN, Sullenger BA. Notch promotes radioresistance of glioma stem cells. Stem Cells. 2010; 28:17-28. https://doi.org/10.1002/stem.261.

14. Ouedraogo ZG, Muller-Barthelemy M, Kemeny JL, Dedieu V, Biau J, Khalil T, Raoelfils LI, Granzotto A, Pereira B, Beaudoin C, Guissou IP, Berger M, Morel L, et al. STAT3 Serine 727 Phosphorylation: A Relevant Target to Radiosensitize Human Glioblastoma. Brain Pathol. 2016; 26:18-30. https://doi.org/10.1111/bpa.12254.

15. Carro MS, Lim WK, Alvarez MJ, Bollo RJ, Zhao X, Snyder EY, Sulman EP, Anne SL, Doetsch F, Colman H, Lasorella A, Aldape K, Califano A, et al. The transcriptional network for mesenchymal transformation of brain tumours. Nature. 2010; 463:318-25. https://doi.org/10.1038/nature08712.

16. Moon SH, Kim DK, Cha Y, Jeon I, Song J, Park KS. PI3K/ Akt and Stat 3 signaling regulated by PTEN control of the cancer stem cell population, proliferation and senescence in a glioblastoma cell line. Int J Oncol. 2013; 42:921-8. https://doi.org/10.3892/ijo.2013.1765.

17. Stechishin OD, Luchman HA, Ruan Y, Blough MD, Nguyen SA, Kelly JJ, Cairncross JG, Weiss S. On-target JAK2/ STAT3 inhibition slows disease progression in orthotopic xenografts of human glioblastoma brain tumor stem cells. Neuro Oncol. 2013; 15:198-207. https://doi.org/10.1093/ neuonc/nos302.

18. Villalva C, Martin-Lanneree S, Cortes U, Dkhissi F, Wager M, Le Corf A, Tourani JM, Dusanter-Fourt I, Turhan AG, Karayan-Tapon L. STAT3 is essential for the maintenance of neurosphere-initiating tumor cells in patients with glioblastomas: a potential for targeted therapy? Int J Cancer. 2011; 128:826-38. https://doi.org/10.1002/ijc. 25416.

19. Sherry MM, Reeves A, Wu JK, Cochran BH. STAT3 is required for proliferation and maintenance of multipotency in glioblastoma stem cells. Stem Cells. 2009; 27:2383-92. https://doi.org/10.1002/stem.185.

20. Akira S, Nishio Y, Inoue M, Wang XJ, Wei S, Matsusaka T, Yoshida K, Sudo T, Naruto M, Kishimoto T. Molecular cloning of APRF, a novel IFN-stimulated gene factor 3 p91-related transcription factor involved in the gp130mediated signaling pathway. Cell. 1994; 77:63-71.

21. Cao X, Tay A, Guy GR, Tan YH. Activation and association of Stat3 with Src in v-Src-transformed cell lines. Mol Cell Biol. 1996; 16:1595-603.

22. Yu CL, Meyer DJ, Campbell GS, Larner AC, Carter-Su C, Schwartz J, Jove R. Enhanced DNA-binding activity of a Stat3-related protein in cells transformed by the Src oncoprotein. Science. 1995; 269:81-3.

23. Giordano V, De Falco G, Chiari R, Quinto I, Pelicci PG, Bartholomew L, Delmastro P, Gadina M, Scala G. Shc mediates IL-6 signaling by interacting with gp130 and Jak2 kinase. J Immunol. 1997; 158:4097-103.

24. Garcia R, Yu CL, Hudnall A, Catlett R, Nelson KL, Smithgall T, Fujita DJ, Ethier SP, Jove R. Constitutive activation of Stat3 in fibroblasts transformed by diverse oncoproteins and in breast carcinoma cells. Cell Growth Differ. 1997; 8:1267-76.

25. Lutticken C, Wegenka UM, Yuan J, Buschmann J, Schindler C, Ziemiecki A, Harpur AG, Wilks AF, Yasukawa K, Taga T, Kishimoto T, Barbieri G, Pellegrini S, et al. Association of transcription factor APRF and protein kinase Jak1 with the interleukin-6 signal transducer gp130. Science. 1994; 263: 89-92.

26. Megeney LA, Perry RL, LeCouter JE, Rudnicki MA. bFGF and LIF signaling activates STAT3 in proliferating myoblasts. Dev Genet. 1996; 19:139-45. https://doi. org/10.1002/(SICI)1520-6408(1996)19:2<139::AID-DVG5 $>3.0 . \mathrm{CO} ; 2-\mathrm{A}$.

27. Wen Z, Zhong Z, Darnell JE Jr. Maximal activation of transcription by Stat1 and Stat 3 requires both tyrosine and serine phosphorylation. Cell. 1995; 82:241-50.

28. Jain N, Zhang T, Kee WH, Li W, Cao X. Protein kinase $\mathrm{C}$ delta associates with and phosphorylates Stat3 in an interleukin-6-dependent manner. J Biol Chem. 1999; 274:24392-400.

29. Wierenga AT, Vogelzang I, Eggen BJ, Vellenga E. Erythropoietin-induced serine 727 phosphorylation of STAT3 in erythroid cells is mediated by a MEK-, ERK-, and MSK1-dependent pathway. Exp Hematol. 2003; 31:398-405.

30. Yokogami K, Wakisaka S, Avruch J, Reeves SA. Serine phosphorylation and maximal activation of STAT3 during CNTF signaling is mediated by the rapamycin target mTOR. Curr Biol. 2000; 10:47-50.

31. Jarnicki A, Putoczki T, Ernst M. Stat3: linking inflammation to epithelial cancer - more than a "gut" feeling? Cell Div. 2010; 5:14. https://doi.org/10.1186/1747-1028-5-14.

32. Fukada T, Hibi M, Yamanaka Y, Takahashi-Tezuka M, Fujitani Y, Yamaguchi T, Nakajima K, Hirano T. Two signals are necessary for cell proliferation induced by a cytokine receptor gp130: involvement of STAT3 in antiapoptosis. Immunity. 1996; 5:449-60. 
33. Loeffler S, Fayard B, Weis J, Weissenberger J. Interleukin-6 induces transcriptional activation of vascular endothelial growth factor (VEGF) in astrocytes in vivo and regulates VEGF promoter activity in glioblastoma cells via direct interaction between STAT3 and Sp1. Int J Cancer. 2005; 115:202-13. https://doi.org/10.1002/ijc.20871.

34. Yu H, Jove R. The STATs of cancer--new molecular targets come of age. Nat Rev Cancer. 2004; 4:97-105. https://doi. org/10.1038/nrc1275.

35. Siveen KS, Sikka S, Surana R, Dai X, Zhang J, Kumar AP, Tan BK, Sethi G, Bishayee A. Targeting the STAT3 signaling pathway in cancer: role of synthetic and natural inhibitors. Biochim Biophys Acta. 2014; 1845:136-54. https://doi.org/10.1016/j.bbcan.2013.12.005.

36. Brantley EC, Benveniste EN. Signal transducer and activator of transcription-3: a molecular hub for signaling pathways in gliomas. Mol Cancer Res. 2008; 6:675-84. https://doi.org/10.1158/1541-7786.MCR-07-2180.

37. Cao Y, Lathia JD, Eyler CE, Wu Q, Li Z, Wang H, McLendon RE, Hjelmeland AB, Rich JN. Erythropoietin Receptor Signaling Through STAT3 Is Required For Glioma Stem Cell Maintenance. Genes Cancer. 2010; 1:50 61. https://doi.org/10.1177/1947601909356352.

38. Guryanova OA, Wu Q, Cheng L, Lathia JD, Huang Z, Yang J, MacSwords J, Eyler CE, McLendon RE, Heddleston JM, Shou W, Hambardzumyan D, Lee J, et al. Nonreceptor tyrosine kinase BMX maintains self-renewal and tumorigenic potential of glioblastoma stem cells by activating STAT3. Cancer Cell. 2011; 19:498-511. https:// doi.org/10.1016/j.ccr.2011.03.004.

39. Kim E, Kim M, Woo DH, Shin Y, Shin J, Chang N, Oh YT, Kim H, Rheey J, Nakano I, Lee C, Joo KM, Rich JN, et al. Phosphorylation of EZH2 activates STAT3 signaling via STAT3 methylation and promotes tumorigenicity of glioblastoma stem-like cells. Cancer Cell. 2013; 23:839-52. https://doi.org/10.1016/j.ccr.2013.04.008.

40. Herrmann A, Cherryholmes G, Schroeder A, Phallen J, Alizadeh D, Xin H, Wang T, Lee H, Lahtz C, Swiderski P, Armstrong B, Kowolik C, Gallia GL, et al. TLR9 is critical for glioma stem cell maintenance and targeting. Cancer Res. 2014; 74:5218-28. https://doi.org/10.1158/0008-5472. CAN-14-1151.

41. Kim KW, Mutter RW, Cao C, Albert JM, Shinohara ET, Sekhar KR, Lu B. Inhibition of signal transducer and activator of transcription 3 activity results in downregulation of Survivin following irradiation. Mol Cancer Ther. 2006; 5:2659-65. https://doi.org/10.1158/1535-7163. MCT-06-0261.

42. Spitzner M, Roesler B, Bielfeld C, Emons G, Gaedcke J, Wolff HA, Rave-Frank M, Kramer F, Beissbarth T, Kitz J, Wienands J, Ghadimi BM, Ebner R, et al. STAT3 inhibition sensitizes colorectal cancer to chemoradiotherapy in vitro and in vivo. Int J Cancer. 2014; 134:997-1007. https://doi. org/10.1002/ijc.28429.
43. Gao L, Li F, Dong B, Zhang J, Rao Y, Cong Y, Mao B, Chen X. Inhibition of STAT3 and ErbB2 suppresses tumor growth, enhances radiosensitivity, and induces mitochondria-dependent apoptosis in glioma cells. Int J Radiat Oncol Biol Phys. 2010; 77:1223-31. https://doi. org/10.1016/j.ijrobp.2009.12.036.

44. Schust J, Sperl B, Hollis A, Mayer TU, Berg T. Stattic: a small-molecule inhibitor of STAT3 activation and dimerization. Chem Biol. 2006; 13:1235-42. https://doi. org/10.1016/j.chembiol.2006.09.018.

45. Iwamaru A, Szymanski S, Iwado E, Aoki H, Yokoyama T, Fokt I, Hess K, Conrad C, Madden T, Sawaya R, Kondo S, Priebe W, Kondo Y. A novel inhibitor of the STAT3 pathway induces apoptosis in malignant glioma cells both in vitro and in vivo. Oncogene. 2007; 26:2435-44. https:// doi.org/10.1038/sj.onc.1210031.

46. Mora LB, Buettner R, Seigne J, Diaz J, Ahmad N, Garcia R, Bowman T, Falcone R, Fairclough R, Cantor A, MuroCacho C, Livingston S, Karras J, et al. Constitutive activation of Stat 3 in human prostate tumors and cell lines: direct inhibition of Stat3 signaling induces apoptosis of prostate cancer cells. Cancer Res. 2002; 62:6659-66.

47. Lin Q, Lai R, Chirieac LR, Li C, Thomazy VA, Grammatikakis I, Rassidakis GZ, Zhang W, Fujio Y, Kunisada K, Hamilton SR, Amin HM. Constitutive activation of JAK3/STAT3 in colon carcinoma tumors and cell lines: inhibition of JAK3/STAT3 signaling induces apoptosis and cell cycle arrest of colon carcinoma cells. Am J Pathol. 2005; 167:969-80. https://doi.org/10.1016/ S0002-9440(10)61187-X.

48. Chung SS, Aroh C, Vadgama JV. Constitutive activation of STAT3 signaling regulates hTERT and promotes stem celllike traits in human breast cancer cells. PLoS One. 2013; 8:e83971. https://doi.org/10.1371/journal.pone.0083971.

49. Pan Y, Zhou F, Zhang R, Claret FX. Stat3 inhibitor Stattic exhibits potent antitumor activity and induces chemoand radio-sensitivity in nasopharyngeal carcinoma. PLoS One. 2013; 8:e54565. https://doi.org/10.1371/journal. pone. 0054565 .

50. Han Z, Wang X, Ma L, Chen L, Xiao M, Huang L, Cao Y, Bai J, Ma D, Zhou J, Hong Z. Inhibition of STAT3 signaling targets both tumor-initiating and differentiated cell populations in prostate cancer. Oncotarget. 2014; 5:841628. https://doi.org/10.18632/oncotarget.2314.

51. Ho JN, Kang GY, Lee SS, Kim J, Bae IH, Hwang $\mathrm{SG}$, Um HD. Bcl-XL and STAT3 mediate malignant actions of gamma-irradiation in lung cancer cells. Cancer Sci. 2010; 101:1417-23. https://doi. org/10.1111/j.1349-7006.2010.01552.x.

52. Li F, Gao L, Jiang Q, Wang Z, Dong B, Yan T, Chen X. Radiation enhances the invasion abilities of pulmonary adenocarcinoma cells via STAT3. Mol Med Rep. 2013; 7:1883-8. https://doi.org/10.3892/mmr.2013.1441.

53. Rahaman SO, Harbor PC, Chernova O, Barnett GH, Vogelbaum MA, Haque SJ. Inhibition of constitutively 
active Stat 3 suppresses proliferation and induces apoptosis in glioblastoma multiforme cells. Oncogene. 2002; 21:8404-13. https://doi.org/10.1038/sj.onc.1206047.

54. Barry SP, Townsend PA, Knight RA, Scarabelli TM, Latchman DS, Stephanou A. STAT3 modulates the DNA damage response pathway. Int J Exp Pathol. 2010; 91:50614. https://doi.org/10.1111/j.1365-2613.2010.00734.x.

55. Xu F, Li X, Yan L, Yuan N, Fang Y, Cao Y, Xu L, Zhang $\mathrm{X}, \mathrm{Xu} \mathrm{L}, \mathrm{Ge} \mathrm{C}$, An N, Jiang G, Xie J, et al. Autophagy Promotes the Repair of Radiation-Induced DNA Damage in Bone Marrow Hematopoietic Cells via Enhanced STAT3 Signaling. Radiat Res. 2017; 187:382-96. https://doi. org/10.1667/RR14640.1.

56. Fang ZH, Li YJ, Chen Z, Wang JJ, Zhu LH. Inhibition of signal transducer and activator of transcription 3 and cyclooxygenase- 2 is involved in radiosensitization of cepharanthine in HeLa cells. Int $\mathrm{J}$ Gynecol Cancer. 2013; 23:608-14. https://doi.org/10.1097/ IGC.0b013e31828a05fd.

57. Adachi M, Cui C, Dodge CT, Bhayani MK, Lai SY. Targeting STAT3 inhibits growth and enhances radiosensitivity in head and neck squamous cell carcinoma. Oral Oncol. 2012; 48:1220-6. https://doi.org/10.1016/j. oraloncology.2012.06.006.

58. Ashizawa T, Miyata H, Iizuka A, Komiyama M, Oshita C, Kume A, Nogami M, Yagoto M, Ito I, Oishi T, Watanabe R, Mitsuya K, Matsuno K, et al. Effect of the STAT3 inhibitor STX-0119 on the proliferation of cancer stem-like cells derived from recurrent glioblastoma. Int J Oncol. 2013; 43:219-27. https://doi.org/10.3892/ijo.2013.1916.

59. Hussain SF, Kong LY, Jordan J, Conrad C, Madden T, Fokt I, Priebe W, Heimberger AB. A novel small molecule inhibitor of signal transducers and activators of transcription 3 reverses immune tolerance in malignant glioma patients. Cancer Res. 2007; 67:9630-6. https://doi.org/10.1158/00085472.CAN-07-1243.

60. Brambilla L, Genini D, Laurini E, Merulla J, Perez L, Fermeglia M, Carbone GM, Pricl S, Catapano CV. Hitting the right spot: Mechanism of action of OPB-31121, a novel and potent inhibitor of the Signal Transducer and Activator of Transcription 3 (STAT3). Mol Oncol. 2015; 9:1194-206. https://doi.org/10.1016/j.molonc.2015.02.012.

61. Oh DY, Lee SH, Han SW, Kim MJ, Kim TM, Kim TY, Heo DS, Yuasa M, Yanagihara Y, Bang YJ. Phase I Study of OPB-31121, an Oral STAT3 Inhibitor, in Patients with Advanced Solid Tumors. Cancer Res Treat. 2015; 47:60715. https://doi.org/10.4143/crt.2014.249.

62. Verhaak RG, Hoadley KA, Purdom E, Wang V, Qi Y, Wilkerson MD, Miller CR, Ding L, Golub T, Mesirov JP, Alexe G, Lawrence M, O'Kelly M, et al. Integrated genomic analysis identifies clinically relevant subtypes of glioblastoma characterized by abnormalities in PDGFRA,
IDH1, EGFR, and NF1. Cancer Cell. 2010; 17:98-110. https://doi.org/10.1016/j.ccr.2009.12.020.

63. Phillips HS, Kharbanda S, Chen R, Forrest WF, Soriano RH, Wu TD, Misra A, Nigro JM, Colman H, Soroceanu L, Williams PM, Modrusan Z, Feuerstein BG, et al. Molecular subclasses of high-grade glioma predict prognosis, delineate a pattern of disease progression, and resemble stages in neurogenesis. Cancer Cell. 2006; 9:157-73. https://doi. org/10.1016/j.ccr.2006.02.019.

64. Cooper LA, Gutman DA, Chisolm C, Appin C, Kong J, Rong Y, Kurc T, Van Meir EG, Saltz JH, Moreno CS, Brat DJ. The tumor microenvironment strongly impacts master transcriptional regulators and gene expression class of glioblastoma. Am J Pathol. 2012; 180:2108-19. https://doi. org/10.1016/j.ajpath.2012.01.040.

65. Arimappamagan A, Somasundaram K, Thennarasu K, Peddagangannagari S, Srinivasan H, Shailaja BC, Samuel C, Patric IR, Shukla S, Thota B, Prasanna KV, Pandey P, Balasubramaniam A, et al. A fourteen gene GBM prognostic signature identifies association of immune response pathway and mesenchymal subtype with high risk group. PLoS One. 2013; 8:e62042. https://doi.org/10.1371/journal. pone. 0062042 .

66. Cheng W, Zhang C, Ren X, Jiang Y, Han S, Liu Y, Cai J, Li M, Wang K, Liu Y, Hu H, Li Q, Yang P, et al. Bioinformatic analyses reveal a distinct Notch activation induced by STAT3 phosphorylation in the mesenchymal subtype of glioblastoma. J Neurosurg. 2016; 1-11. https://doi. org/10.3171/2015.11.JNS15432.

67. Lin GS, Chen YP, Lin ZX, Wang XF, Zheng ZQ, Chen L. STAT3 serine 727 phosphorylation influences clinical outcome in glioblastoma. Int J Clin Exp Pathol. 2014; 7:3141-9.

68. Lin GS, Yang LJ, Wang XF, Chen YP, Tang WL, Chen L, Lin ZX. STAT3 Tyr705 phosphorylation affects clinical outcome in patients with newly diagnosed supratentorial glioblastoma. Med Oncol. 2014; 31:924. https://doi. org/10.1007/s12032-014-0924-5.

69. Balbous A, Cortes U, Guilloteau K, Villalva C, Flamant S, Gaillard A, Milin S, Wager M, Sorel N, Guilhot J, Bennaceur-Griscelli A, Turhan A, Chomel JC, et al. A mesenchymal glioma stem cell profile is related to clinical outcome. Oncogenesis. 2014; 3:e91. https://doi. org/10.1038/oncsis.2014.5.

70. Balbous A, Renoux B, Cortes U, Milin S, Guilloteau K, Legigan T, Rivet P, Boissonnade O, Martin S, Tripiana C, Wager M, Bensadoun RJ, Papot S, et al. Selective release of a cyclopamine glucuronide prodrug toward stem-like cancer cell inhibition in glioblastoma. Mol Cancer Ther. 2014; 13:2159-69. https://doi.org/10.1158/1535-7163. MCT-13-1038. 